\title{
Introduction
}

by T. Agmon* and Y. Kahane*

The papers in this issue are based on presentations made in a symposium on insurance of international trade risk which took place at Tel Aviv University in conjunction with the annual meetings of the International Union of Credit and Investment Insurers (known as the "Berne Union"). The symposium, which took place in October 1985, was jointly organized by The Israeli Foreign Trade Risks Insurance Corporation (IFTRIC) and the Executive Development Programs and the Erhard Insurance Center at the Faculty of Management, Tel Aviv University, and was academically coordinated by the undersigned.

The symposium covered a large number of topics; only part of them are being reported here. It was concluded with strong feeling that much could be gained from the interaction between the academic and practitioner in the field. A few topics emerged as deserving special attention for further study; among them are: the assessment of counry risk through analysis of past and forecasted indicators; the analysis of country risks from a broad point of view (the risk may originate in another country), and the use of objective and subjective evaluations in making such assessments; the development of better and more sophisticated insurance and risk management techniques and tools.

Although the papers are very different from each other and they range from academic papers to presentations and statements, we feel that as a whole they provide a comprehensive picture of the activities of the Berne Union and the issues associated with its specific brand of insurance. Some of the contributors are prominent figures in the field and we are happy to have the opportunity to learn about their views, and gain from their experience in the field.

We would like to thank IFTRIC and especially its general manager, Mr. A. Kamir, and the Secretariat of the Berne Union which made this symposium possible. And, of course, we wish to thank the participants of the symposium, and especially those who agreed to put their views and ideas in writing to be presented in this compendium.

Below is a short description and abstract of the papers in the order of their printing:

1. The Role of The Berne Union

by Mr. Donald A. Ward, Secretary

International Union of Credit and Investment Insurers

London - United Kingdom

* Tel Aviv University 
This is a descriptive statement by the secretary of the union, which provides the institutional setting for the rest of the papers.

\section{Protection and export insurance. The identification and measurement of international trade risks}

by Prof. T. Agmon. Tel Aviv University - Israel.

This paper deals with the definition and the measurement of the risk to be insured by international trade risks insurers. The emphasis is on the political source of the risk. Contrary to popular belief, the author argues that the source of the risk is frequently found at the target market of the developed countries rather than at the developing countries.

\section{The management of international trade risks}

by Prof. Donald R. Lessard

Graduate School of Business - Stanford University and Sloan School Management, M.I.T.

This paper deals with the comparative advantage of various participants in the market to carry international trade risk. The author argues that investors, financial institutions, export credit insurers and governments should take part in the insurance of various types of international trade risk. This paper takes off from the classification presented in the previous (Agmon's) paper, and suggests some managerial techniques applied to actual cases of international risk management. For example, a division between micro and macro on one hand, and the allocation of the various risks to government agencies and private insurers, on the other hand.

\section{Export credit insurance - why government}

by Mr. J. Gill Chairman

The Export Credit Guarantee Department (ECGD)

London - United Kingdom

This presentation provides an explanation for the government involvement in export credit insurance. The author shows, through a description of the ECGD, the role of the government and how the insurance is carried out by the ECGD.

\section{Some comments on the present consensus arrangement and its implication for world trade}

by Mr. A. Wallen

Exportkredit

Stockholm - Sweden

Export insurance is closely related to other forms of support and subsidies for export. One of the most common of those is the use of subsidised financing. Mr. Wallen addresses the issue of the consensus arrangement and its implications for world trade. He shows that the consensus arrangement is the outcome of contradictory forces; those trying to limit subsidies versus political pressures which push towards more subsidies. Like all compromises it is open to criticism but it may still be the best solution. 


\section{Insurance and risk management of foreign trade risks}

by Prof. Y. Kahane

Academic Director, Erhard Insurance Center

Tel Aviv University - Israel.

In this paper Kahane examines the applicability of the traditional insurance principles for the area of international trade risks. It is shown that insurance of foreign risks does not always meet these basic principles. Even the term "trade risk" in itself is associated with situation of negative profitability rather than with risky (uncertain) situations. The author points out the need for reinsurance arrangement in this area.

It is suggested that the insurance of foreign trade risks could be viewed as a process of information exchange. The insurance would be carried by the organization which is most effective in collecting and processing information.

\section{Export credit insurance and the debt crisis}

by Prof. Dr. Helmut H. Haschek, Chairman of the Board and General Manager

Österreichische Kontrollbank

Vienna - Austria

Dr. Haschek provides an interesting view of the relationship between export credit insurance and the financial status of developing countries. Dr. Haschek adopts a system's view relating the commercial banking sector, the world's exporters and importers and the respective governments and he argues that the only possible solution is the one which will involve all the participants in the markets, as well as political understanding among the major governments.

\section{The boundaries of credit insurance}

by J.W. Hoobroeckx, President, The Berne Union

The Netherlands Credit Insurance Company

Holland

This is a short comment highlighting the major limitations of export credit insurance. The author puts forward the view that between the inherent limitations of this type of insurance and the financial problems associated with some of the insureds, the ability of export insurance agencies to provide solutions is quite limited.

\section{Some observations of the use of social and political indicators in international trade risk assessment}

by Dr. Aran Schloss

The Hebrew University

Jerusalem - Israel.

The contribution of this paper lies mainly in its different view-point; whereas the earlier papers dealt with international trade risk as a financial problem Dr. Schloss, being a political scientist, emphasizes the social and political aspects. This paper has a rather lengthy appendix, which provides, however, detailed illustrations for political risk assessments. This type of assessment can be useful as background for more particular financial and insurance decisions. 